

International Journal of Emerging Technology and Advanced Engineering

Website: www.ijetae.com (E-ISSN 2250-2459, Scopus Indexed, ISO 9001:2008 Certified Journal, Volume 11, Issue 10, October 2021)

Manuscript Received: 03 September 2021, Received in Revised form: 10 October 2021, Accepted: 14 October 2021

DOI: 10.46338/ijetae1021_09

\title{
Design of a Robotic Arm Window Cleaner at the Heights to Avoid Accidents Due to Falls
}

\author{
Taylor Sevillano-Visarga ${ }^{1}$, Brian Meneses-Claudio ${ }^{2}$, Alexi Delgado $^{3}$ \\ ${ }^{1,2}$ Universidad de Ciencias y Humanidades \& Av. Universitaria 5175, Los Olivos 15304 \\ ${ }^{3}$ Pontificia Universidad Católica del Perú \& Av. Universitaria 1801, San Miguel 15088
}

\begin{abstract}
Working at height is extremely dangerous because there is not much safety for the worker, for that reason there are accidents of falls from scaffolding. According to the Ministerio de Trabajo y Promoción de Empleo (MTPE) $5.49 \%$ are accidents caused in work at heights. It is important to bear in mind that the higher the height there is more possibility of suffering a fall, therefore, there are many factors in the height, the main factor is the air since it does not allow the scaffold to remain still. That is why, this research work proposes the design of a robotic arm with 5 degrees of freedom with Arduino Mega 2560 and a link with Radio Frequency (RF), to replace the worker and reduce the risk of accident, also consider that the robotic arm will be manipulated wirelessly, being ideal to prevent a fall of personnel and controllable from a safe area. It was obtained as a result, that the robotic arm with 5 degrees of freedom is more than enough to perform a cleaning of three types of windows, and the programming for the robotic arm is quite easy and can be programmed very quickly, in addition the SolidWorks software helps to design and layout the robotic arm.
\end{abstract}

Keywords-- Work at height, scaffolding, robotic arm, SolidWorks, Arduino.

\section{INTRODUCTION}

Work at heights is work where the main factor is the height where there is a greater movement of the scaffold, it is also considered a risky work where they are exposed to accidents, according to international standards the work carried out from 1.80 meters height based on the American National Standard Institute (ANSI) is already considered a risky height work because without having knowledge of the risks and without being trained or having a height work certificate [1].
The work at height has 3 levels; at the first level, it is focusing on workers where they will acquire the necessary knowledge about technique, practice and equipment necessary for safety at high altitudes; the second level is focused on preventive personnel whose task is to supervise all workers and must also have their own knowledge such as management systems, hazard and risk analysis, correct use of ladders and scaffolding, identification of anchor points; the third level is focused on preventive personnel or headquarters who have the task of verifying that all workers respect practices at height and have knowledge of levels 1 and 2, they must also have their own knowledge such as a rescue plan, a complete protection plan against falls, structure evaluation for anchor points and more [2].

In Peru, the most common accident is at heights in 2016, according to the Ministerio de Trabajo y Promoción del Empleo (MTPE) revealed exact figures, 20876 occupational accidents were registered, including this height accident [3]. According to the (MTPE), during 2019 the cases of work accidents increased $73 \%$ compared to 2018 [4]. Falls or accidents suffered at the time of performing a work at heights suffer accidents or deaths $5.49 \%$ [3].

In Spain, according to the report prepared by the federation of construction and services of the commission union in the year of 2019 between January and May, a total of 28970 accidents have been registered, $41 \%$ are produced at different levels of falls from height, $30 \%$ is caused by falls from scaffolds [4].

The main objective of this research work is to reduce the accidents suffered by workers in the heights when cleaning the windows, as well as to avoid falls or injuries in the workers of these companies. 


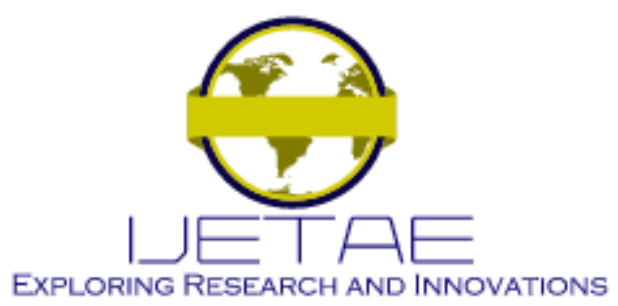

International Journal of Emerging Technology and Advanced Engineering

Website: www.ijetae.com (E-ISSN 2250-2459, Scopus Indexed, ISO 9001:2008 Certified Journal, Volume 11, Issue 10, October 2021)

With this design proposal, it would be possible to reduce the work time of the personnel in which the company would benefit, likewise it could prevent the risks of falls that people have when carrying out this type of work, finally, this work that is proposed has a low cost to implement in any organization.

The Arduino software is open source, this software can be used with any Arduino programming board [5], the Arduino Mega 2560 was used because it has more digital pins as analog pins, the Arduino software is easier to program and can be used in many projects, because it can be used digitally or analog, this software is simpler than other software that exists to program.

SolidWorks is a software that allows designing in 3D as well as in 2D [6], this platform is easy to use because it can be found in several languages unlike other platforms, they can be designed in 3D part, part assembly and drawing its construction in $2 \mathrm{D}$ is very fast and has many more functions, as well as the simulation of the parts.

This research work has the following sections, in section II, the literature view, in section III, it deals with the design of each of the parts of the robotic arm that was elaborated are the SolidWorks software and the movement of the servomotors, in section IV the results are shown of the robotic arm as well as the complete design of the same, in $\mathrm{V}$ there are the discussions of research work, finally in section VI the conclusions, future works and recommendations are mentioned.

\section{LITERATURE REVIEW}

In [7], this article made a trajectory generation robotic arm (Armx) with four degrees of freedom and a threedimensional movement using an Arduino Mega 2560 board, using a National Instruments LabWindows / CVI 9.0 software which will allow to connect with PC and user, send coordinate data for movement. The author concluded that this robotic arm can be applied in different fields of work for the benefit of the person.

In [8], the research work carried out a wireless robotic arm for high-risk tasks that involve people's lives, this arm is controlled with a sensory glove and flex sensors that are on each of the fingers, wireless communication is through the Bluetooth $\mathrm{HC} 05$ and its maximum distance is 20 meters. The author concludes that a robotic arm helps prevent accidents and is very necessary for risky jobs.
In [9], the research work presents the design and assembly of a robot arm as a laboratory module for scanning curves in 3D through an interface in MATLAB, where Arduino software was used for its automatic robotic arm movement that has 5 degrees of freedom, it has error results of $3 \%$ for single curves and $11 \%$ for long curves. However, the author concluded that it is a basic robotic arm that can be used in laboratories.

In [10], this research work carried out an implementation of a robotic arm for the auscultation of the oral cavity using an Arduino board for the assembly and development of the software, and thus the software will allow to make the movements of the robotic arm and thus having communication between the plate and the IoT platform (Cayenne myDevices), with the implementation of the project, it was possible to improve the auscultation of the oral cavity and patient care.

In [11], this research work realized a design and implementation of a robotic arm with 3 degrees of freedom based on the Arduino platform that is focused to carry out practices in hardware laboratories was carried out. It has a remote-control system through a mobile device using wireless communication with the Bluetooth module (HC05). The author concluded that the application is easy to use and is compatible with any device that has bluetooth.

In [12], this thesis made a design of a robotic arm with 6 degrees of freedom for the painting of blades and thus be able to make the paintings with more precision and quality, using a graphical interface (GUI) that allows the user to interact with the robotic arm and also observe the behavior of the variables, the design proposed by the authors of the robot evaluating the advantages and disadvantages was obtained that with 6 degrees of freedom of manipulation is more appropriate for this work.

\section{METHODOLOGY}

The development and construction of the wirelessly controlled smart robotic arm with Arduino Mega with 5 degrees of freedom because it will facilitate the cleaning of the windows likewise one of the advantages of the robotic arm is that it will be able to have greater accessibility to the different types of windows and the disadvantage is that when using 5 degrees of freedom 5 servomotors are used and a battery with many amperages (A) so that the robot has a good duration when cleaning, was performed the following steps. 


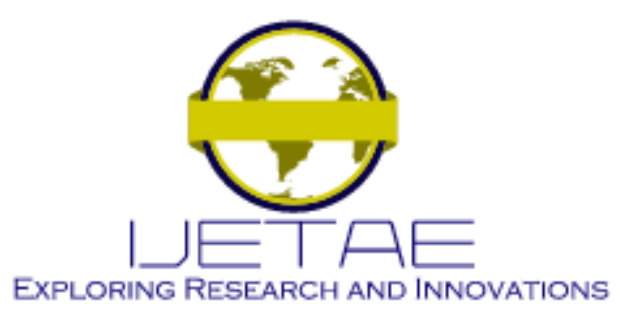

International Journal of Emerging Technology and Advanced Engineering

Website: www.ijetae.com (E-ISSN 2250-2459, Scopus Indexed, ISO 9001:2008 Certified Journal, Volume 11, Issue 10, October 2021)

\section{A. Robotic Arm Design}

For the elaboration and design of the robotic arm, it was necessary to consider three types of windows that were evaluated (window without borders, window with small border and window with large borders), once we had the models of the windows, we proceeded to design the arm robotic consisting of 5 parts. To carry out the design, it used SolidWorks software, which uses a Microsoft Windows-based graphic that allows creating solid models in 3D and 2D plan [6].

\section{B. Table of measurements of parts in SolidWorks}

\begin{tabular}{|c|c|c|c|}
\hline Pieces & $\mathrm{L}$ & $\mathrm{W}$ & $\mathrm{D}$ \\
\hline $\begin{array}{c}\text { Robot } \\
\text { body }\end{array}$ & $25 \mathrm{~cm}$ & $10 \mathrm{~cm}$ & $30 \mathrm{~cm}$ \\
\hline $\begin{array}{c}\text { Robot } \\
\text { arm }\end{array}$ & $30 \mathrm{~cm}$ & $10 \mathrm{~cm}$ & $14 \mathrm{~cm}$ \\
\hline $\begin{array}{c}\text { Robot } \\
\text { forearm }\end{array}$ & $30 \mathrm{~cm}$ & $13 \mathrm{~cm}$ & $15 \mathrm{~cm}$ \\
\hline $\begin{array}{c}\text { Robot } \\
\text { wrist }\end{array}$ & $20 \mathrm{~cm}$ & $10 \mathrm{~cm}$ & $10 \mathrm{~cm}$ \\
\hline $\begin{array}{c}\text { Robot } \\
\text { hand }\end{array}$ & $15 \mathrm{~cm}$ & $10 \mathrm{~cm}$ & $10 \mathrm{~cm}$ \\
\hline $\begin{array}{c}\text { Robot } \\
\text { base }\end{array}$ & $30 \mathrm{~cm}$ & $20 \mathrm{~cm}$ & $15 \mathrm{~cm}$ \\
\hline
\end{tabular}

\section{1) Step 1:}

The first design that was made with the SolidWorks software is the body of the robotic arm, which is also a support for the second part, which is the robot arm. Figure 1 shows the body of the robot.

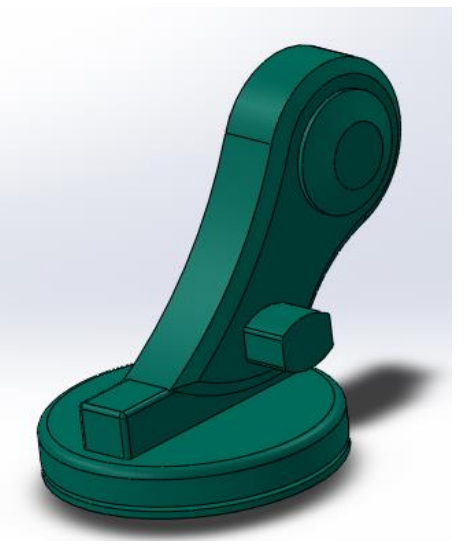

Fig. 1. Robotic Arm Body

\section{2) Step 2:}

The second design that was made with the SolidWorks software is the robot arm that allows the forearm to be moved up and down, in Figure 2 the robot's forearm is shown.

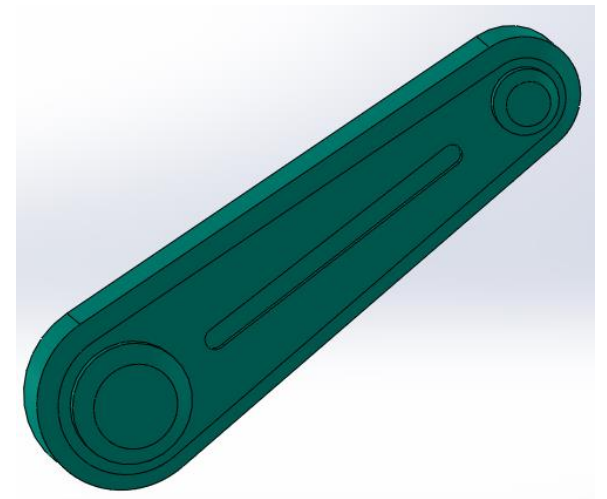

Fig. 2. Robotic Arm Body

\section{3) Step 3:}

The third design that was made with the SolidWorks software is the robot's forearm, which is a support for the fourth piece, which is the robot's wrist that has a rotational movement, in Figure 3 the robot's forearm is shown.

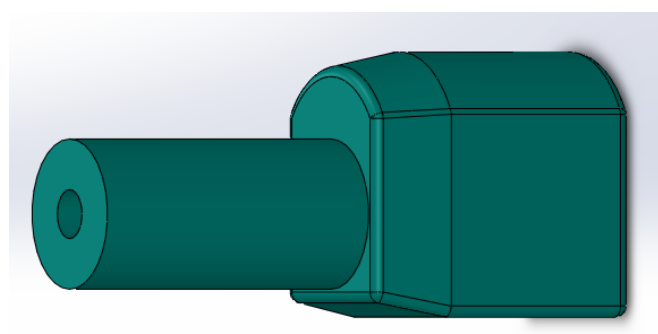

Fig. 3. Robot Forearm

\section{4) Step 4:}

The fourth design that was made with the SolidWorks software is the robot's wrist, which joins the fifth piece. Figure 4 shows the robot's wrist. 


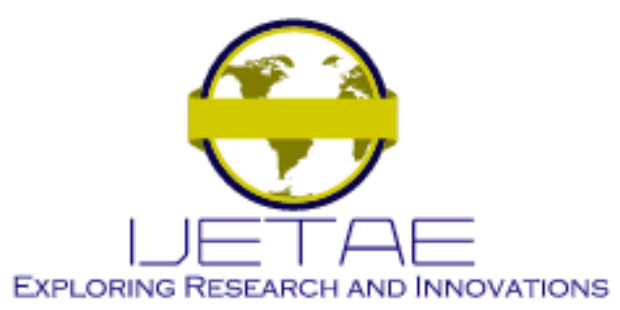

International Journal of Emerging Technology and Advanced Engineering

Website: www.ijetae.com (E-ISSN 2250-2459, Scopus Indexed, ISO 9001:2008 Certified Journal, Volume 11, Issue 10, October 2021)

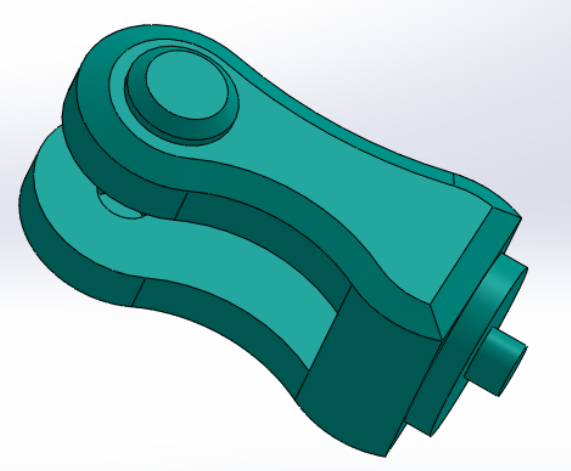

Fig. 4. Wrist of the Robotic Arm

\section{5) Step 5:}

As the last design that was made with the SolidWorks software of the robotic arm, it was a piece that is attached to the wrist, Figure 5 shows the piece or hand of the robot.



Fig. 5. Part or Hand of the Robotic Arm.

\section{Design of the bases}

To design the base of the robotic arm, the hanging scaffold was taken into consideration. First, scaffold is hung and is subject to ropes at the edges; its greatest advantage is that it does not have an anchor to the scaffold support, which will allow us to carry out various types of work such as (painting, window cleaning, frame cleaning, etc.) as well as in some buildings their facades must be clean [13], that is why a base for the robotic arm was designed that allows its easy movement as shown in Figure 6, the weight that a hanging scaffold can support is 208 Kilograms [14].

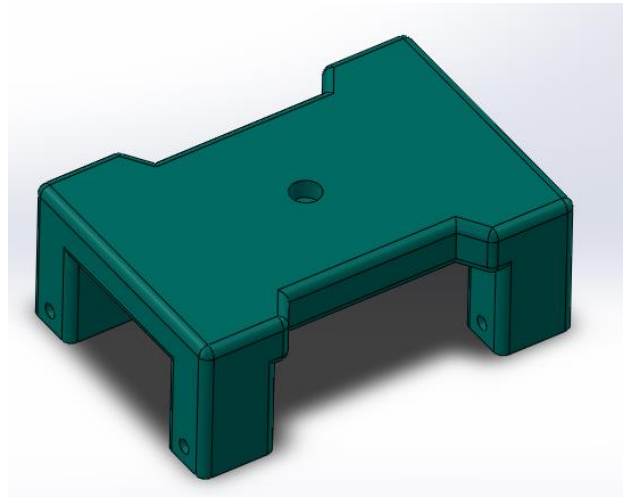

Fig. 6. Robot Arm Base

\section{Design of Degrees of Movement}

To perform the movement of the robotic arm that consists of 5 degrees of freedom, first is the operation of the servomotor, a servomotor has a special type of motor with specific characteristics for position control that are from $0^{\circ}$ to $360^{\circ}$ degrees, to carry out the movement, a PWM (Pulse-Width Modulation) signal [15], is needed, a DRV8312 chip [16] is used to control the speed of the linear motor.

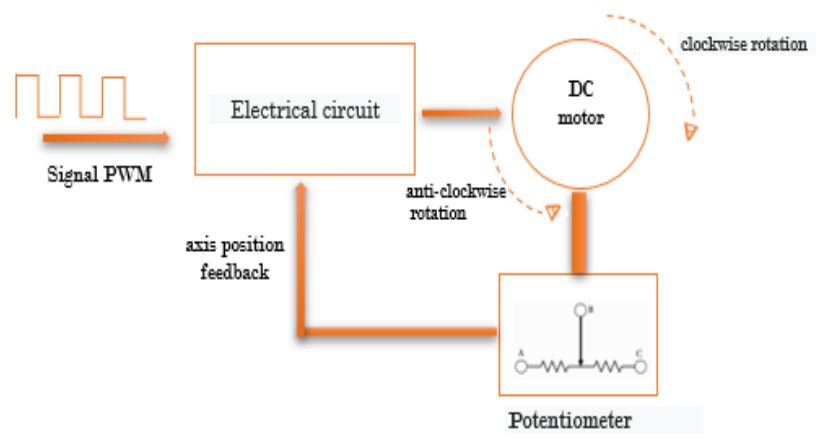

Fig. 7. Block diagram of a servomotor

Once the function of the servomotor has been observed, the robotic arm can have 2 joints, linear and rotational, the degree of freedom is a movement in a three-dimensional space where it can move forward / backward, up / down, left / right and the movement of the axes is independent [17], in a robot the speed of the electric motor is important at low speed it is easier to control the positioning [18]. 


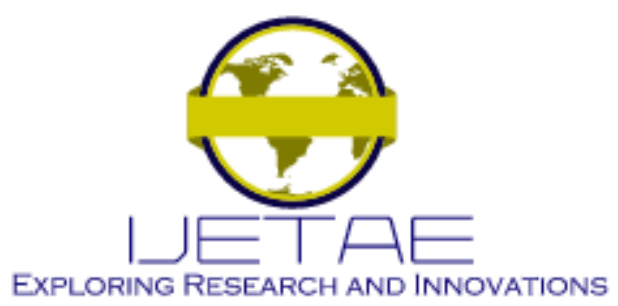

International Journal of Emerging Technology and Advanced Engineering

Website: www.ijetae.com (E-ISSN 2250-2459, Scopus Indexed, ISO 9001:2008 Certified Journal, Volume 11, Issue 10, October 2021)

\section{E. Detect Window Design}

To detect the shape of the window, the robotic arm will have a camera that will allow it to see the model of the window, the camera module is ESP32-CAM, which is WIFI wireless, it allows making videos by creating a local server on the same chip. Another function such as facial recognition, among the main applications are IP video surveillance camera, camera controller to transmit images [19]. It is compatible to program with Arduino software, Figure 8 shows a convert that will be used for programming.

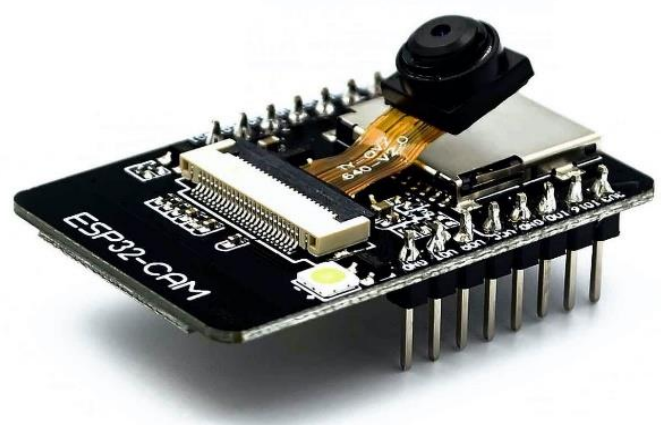

Fig. 8. ESP32-CAM module



Fig. 9. USB to TTL converter (FT232RL FTDI)

The first step is to create an algorithm for the ESP32CAM camera with Arduino software, it will have to use a USB to TTL converter (FT232RL FTDI), the second step is that the camera has a $360^{\circ}$ rotation with the help of a servomotor.

\section{F. Robotic Arm Movement}

The algorithm that was carried out for the robotic arm is that it can be moved depending on how the user wishes, for that the Arduino software was used, which is free to access, it is open source, it facilitates the structure of the code and its loading to the board works on Windows, this software can be used on any Arduino board [5].

For the movements of the robotic arm, an algorithm was structured in the Arduino software, which is made up of 5 structures.

1. The first step of the algorithm that was carried out for the robotic arm, that is, the first piece can be seen in Figure 1 that can be moved (clockwise and counterclockwise).

2. The second algorithm that was carried out for the second piece that can be seen in Figure 2, has a vertical movement (up and down) the degree of movement is from $0^{\circ}$ to $200^{\circ}$ degrees.

3. The third algorithm that was carried out for the third piece that can be seen in Figure 3, has a vertical movement, the degree of displacement from $0^{\circ}$ to $250^{\circ}$ degrees.

4. The fourth algorithm that was performed for the fourth piece that can be seen in Figure 4, has a rotary movement (counterclockwise), the degree of movement is limited.

5. The fifth algorithm that was performed for the fifth part that can be seen in Figure 5, has a vertical movement (up and down) the degree of displacement from $0^{\circ}$ to $200^{\circ}$ degrees.

\section{RESULTS}

\section{A. Robot arm algorithm.}

The ESP32-CAM algorithm:

Include the ESP32 library and the WIFI module for the program to run normally.

\#include "esp_camera.h"

\#include <WiFi.h>

Select the model of the camera to be used.

\section{\#define CAMERA_MODEL_AI_THINKER}

In addition, a name will be given to the WIFI network that will be used as well as the same password of the WIFI network so that it can be connected, the programming being the following: 


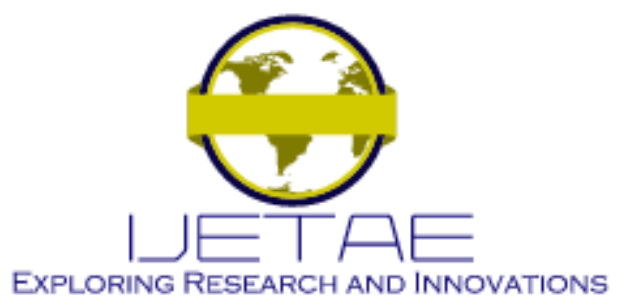

International Journal of Emerging Technology and Advanced Engineering

Website: www.ijetae.com (E-ISSN 2250-2459, Scopus Indexed, ISO 9001:2008 Certified Journal, Volume 11, Issue 10, October 2021)

const char* ssid = "RedSevi-2.4GHZ*"

const char* password = "12345678"

As it can investigate, the ESP32-CAM camera already has a pre-established example in the Arduino software where it is declared pin by pin.

The algorithm of the robotic arm: 2 Arduino Mega was used the radio frequency module is (NRF24) transceiver.

\section{1) Transmitter:}

To define the transmitter library in the Arduino it is required: include NRF24 library to carry out the programming.

$$
\begin{aligned}
& \text { \#include <nRF24L01.h> } \\
& \text { \#include < printf.h> } \\
& \text { \#include <RF24.h> } \\
& \text { \#include <RF24_config.h> }
\end{aligned}
$$

The pins are the same in transmitter and receiver for Arduino Mega to communicate with the radio frequency module.

\section{RF24 radio $(7,8)$; // CE, CSN}

A password was created for it to connect, it must be the same in the transmitter and the receiver.

$$
\text { const byte password [5] = "00008" }
$$

Then, we define the variables of the potentiometers in the analog port.

$$
\begin{aligned}
& \text { int pot_01; } \\
& \text { int pot_02; } \\
& \text { int pot_03; } \\
& \text { int pot_04; } \\
& \text { int pot_05; }
\end{aligned}
$$

After declaring the library, we declare the functionality of each pin and indicating if it is an output or input and start the NRF24 communication for this, the following program will be used.

$$
\begin{aligned}
& \text { pinMode(A1, INPUT); } \\
& \text { pinMode(A2, INPUT); } \\
& \text { pinMode(A3, INPUT); } \\
& \text { pinMode(A4, INPUT); } \\
& \text { pinMode(A5, INPUT); } \\
& \text { radio.begin(); } \\
& \text { radio.openWritingPipe(password); }
\end{aligned}
$$

After declaring the variables and the pins, it will proceed to start with the potentiometer programming and for this it will be in the Loop section of the Arduino:

First pin $\mathrm{A} 1$ potentiometer from $0^{\circ}$ to $360^{\circ}$ degrees.

$$
\text { \{ }
$$$$
\text { pot_01 = map }(\text { analogRead[A1], 0, 1023, 0, 360); }
$$$$
\text { bool fal_ver = radio.write(\&pot_01, }
$$$$
\text { sizeof(pot_01)); }
$$$$
\text { delay(10); }
$$$$
\}
$$

Second potentiometer pin A2 from $0^{\circ}$ to $200^{\circ}$ degrees.

$$
\{
$$$$
\text { pot_02 }=\operatorname{map}(\operatorname{analogRead}[\mathrm{A} 2], 0,1023,0,200) \text {; }
$$$$
\text { bool fal_ver }=\text { radio.write }(\& \text { pot_02, }
$$

Third pin A3 potentiometer from $0^{\circ}$ to $250^{\circ}$ degrees. \{ pot_03 = map $(\operatorname{analogRead}[\mathrm{A} 3], 0,1023,0,250)$;

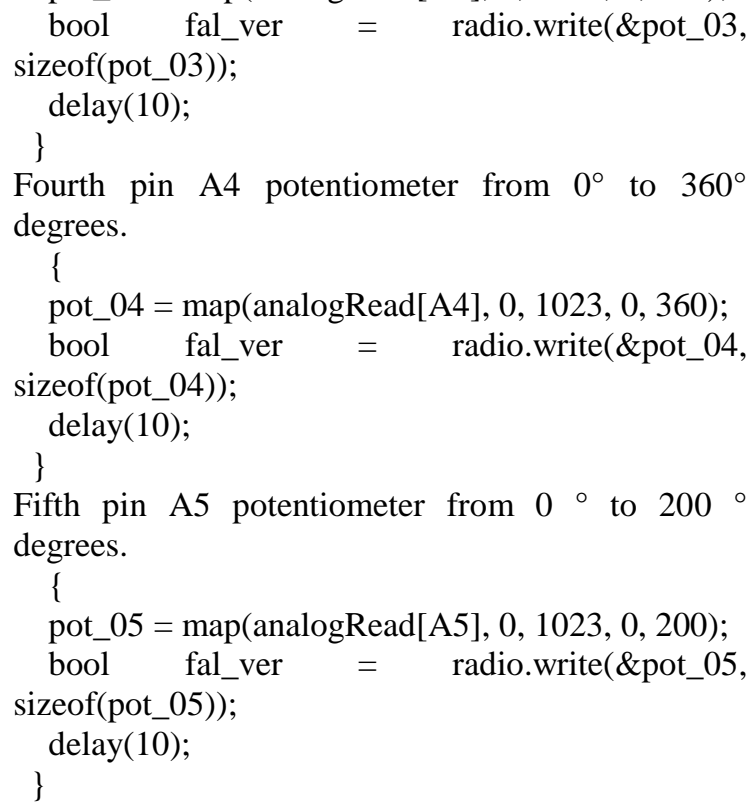

2) Receiver:

To define the receiver library in the Arduino it is required: include the NRF24 library and the servo library. 


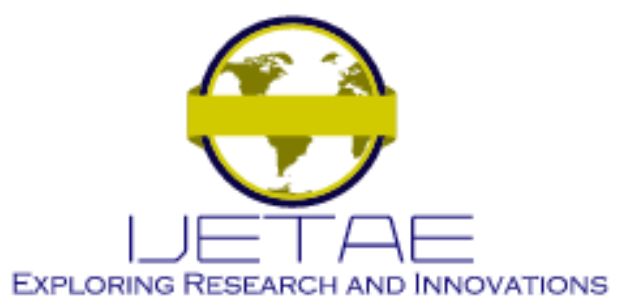

International Journal of Emerging Technology and Advanced Engineering

Website: www.ijetae.com (E-ISSN 2250-2459, Scopus Indexed, ISO 9001:2008 Certified Journal, Volume 11, Issue 10, October 2021)



The pins are the same in transmitter and receiver for Arduino Mega to communicate with the radio frequency module.

A password is created to connect them, it must be the same in the transmitter and the receiver.

The variable where the angles will be stored is defined:

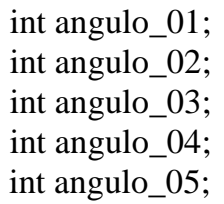

Then, naming the servomotors this will allow us to know which servo is being called to execute the movement.
Servo servo_01;
Servo servo_02;
Servo servo_03;
Servo servo_04;
Servo servo_05;

After declaring the library, the functionality of each pin is declared and indicating whether it is an output or an input, likewise starting the NRF24 communication for this the following program will be used.

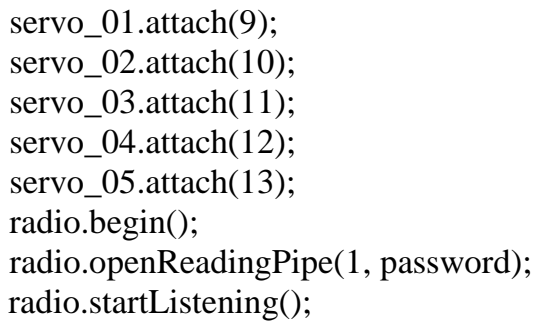

After declaring the variables and the pins, we proceed to start with the programming of the servomotors, it will be in the Loop section of the Arduino:

First servo motor that rotates from $0^{\circ}$ to $360^{\circ}$ degrees

if (radio.available ()$)\{$

radio.read(\&angulo_01, sizeof(angulo_01)); servo_01.write(angulo_01);

$\operatorname{delay}(10)$;

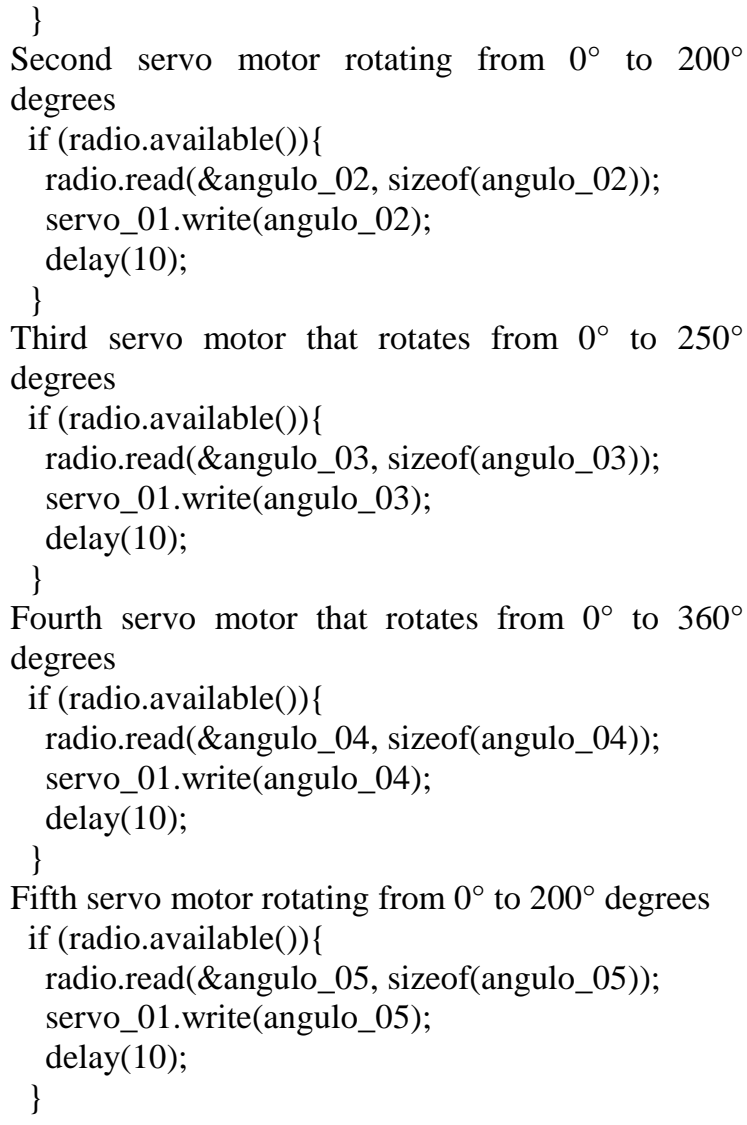

B. Complete Robotic Arm Design.

As shown in Figure 10, there is already the complete design of the robotic arm with 5 degrees of freedom, each of its parts has an independent movement as seen in the image, the base of the robot is joined with the body of the robot, its movement is rotational (clockwise and counterclockwise), the next piece that joins is the robot arm with the body this will allow to move the arm vertically (up and down) with $200^{\circ}$ degrees of freedom, the next piece that joins is the robot's forearm, it is held with the robot arm, this will allow a vertical movement of $250^{\circ}$ degrees, the next piece that joins is the robot's wrist that is attached to the forearm, this will allow a rotational movement and the last piece is joined with the wrist that will allow a movement of $200^{\circ}$ degrees and the sense of movement is vertical, horizontal and diagonal, these movements will depend on how the wrist of the robotic arm is located, the design is optimal for three types of windows that were previously evaluated. 


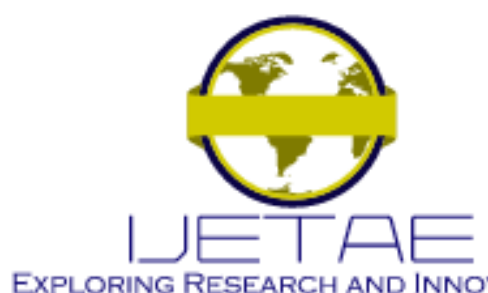

\section{EXPLORING RESEARCH AND INNOVATIONS}

International Journal of Emerging Technology and Advanced Engineering

Website: www.ijetae.com (E-ISSN 2250-2459, Scopus Indexed, ISO 9001:2008 Certified Journal, Volume 11, Issue 10, October 2021)



Fig. 10. Robotic arm.

In Figure 11, it can see how the robotic arm is positioned to proceed with cleaning the window.

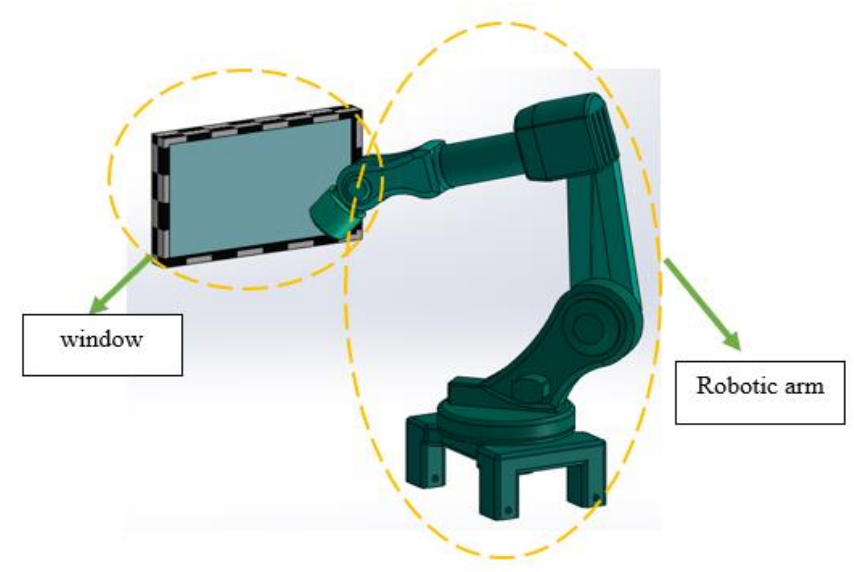

Fig. 11. Robotic Arm-Window

C. Comparison table of robotic arms

TABLE 1

ROBOTIC ARM BUDGET

\begin{tabular}{|c|c|c|c|}
\hline Materials & Unit price & Quantity & Final price \\
\hline Arduino mega 2560 & $\mathrm{S} / .50,00$ & 2 & $\mathrm{~S} / .100,00$ \\
\hline servomotor mg946r & $\mathrm{S} / .30,00$ & 8 & $\mathrm{~S} / 240,00$ \\
\hline Modulo NRF24 & $\mathrm{S} / .50,00$ & 2 & $\mathrm{~S} / .100,00$ \\
\hline ESP32-CAM & $\mathrm{S} / .50,00$ & 1 & $\mathrm{~S} / .50,00$ \\
\hline $\begin{array}{c}\text { USB to TTL } \\
\text { Converter (FT232RL } \\
\text { FTDI) }\end{array}$ & $\mathrm{S} / .17,00$ & 1 & $\mathrm{~S} / 17,00$ \\
\hline Potentiometer & $\mathrm{S} / .2,00$ & 6 & $\mathrm{~S} / .12,00$ \\
\hline Bearing 12x22x9mm & $\mathrm{S} / .5,00$ & 1 & $\mathrm{~S} / .5,00$ \\
\hline \multicolumn{3}{|c|}{ Total } & $\mathrm{S} / .524 .00$ \\
\hline
\end{tabular}

In the following table, the author Troncos [20], shows the materials that it used to implement a mechanical robotic arm with 5 degrees of freedom.

TABLE 2

ROBOTIC ARM BUDGET

\begin{tabular}{|c|c|c|c|c|}
\hline & Materials & $\begin{array}{l}\text { Unit } \\
\text { price }\end{array}$ & Quantity & Final price \\
\hline 1 & $\begin{array}{c}\text { Electronic Board } \\
\text { with Arduino } \\
\text { Nano w / } \\
\text { ATmega328 }\end{array}$ & S/. 60,00 & 1 & S/. 60,00 \\
\hline 2 & $\begin{array}{c}\text { Incremental } \\
\text { Encoder GHS38 } \\
\text { Series }\end{array}$ & $\begin{array}{c}\text { S/. } \\
336,30\end{array}$ & 5 & $\begin{array}{c}\mathrm{S} / . \\
1.681,50\end{array}$ \\
\hline 3 & $\begin{array}{c}\text { Thrust Bearing } \\
51101\end{array}$ & S/. 5,00 & 10 & S/. 50,00 \\
\hline 4 & Pieces of Ertalyte & $\begin{array}{c}\mathrm{S} / . \\
939,57\end{array}$ & 1 & S/. 939,57 \\
\hline 5 & Base Disc & $\mathrm{S} / .10,00$ & 1 & S/. 10,00 \\
\hline 6 & Base & $\mathrm{S} / .10,00$ & 1 & S/. 10,00 \\
\hline 7 & Push button & S/. 5,00 & 1 & S/. 5,00 \\
\hline 8 & Union plate & S/. 0,50 & 5 & S/. 2,50 \\
\hline 9 & Horn & S/. 1,00 & 5 & S/. 5,00 \\
\hline 10 & Machining Works & S/. 60,00 & 1 & S/. 60,00 \\
\hline 11 & $\begin{array}{c}\text { Hexagon head } \\
\text { bolt M12 - Half } \\
\text { thread }\end{array}$ & S/. 1,50 & 5 & S/. 7,50 \\
\hline 12 & Hex nut M12 & S/. 0,50 & 5 & S/. 2,50 \\
\hline 13 & $\begin{array}{c}\text { Hexagon head } \\
\text { screw M4 }\end{array}$ & S/. 0,30 & 14 & S/. 4,20 \\
\hline 14 & $\begin{array}{l}\text { M4 Hex Headless } \\
\text { Screw - Set }\end{array}$ & S/. 0,80 & 5 & S/. 4,00 \\
\hline 15 & $\begin{array}{l}\text { Hexagon head } \\
\text { screw M3 }\end{array}$ & S/. 0,20 & 5 & $\mathrm{~S} / .1,00$ \\
\hline & & & & $\begin{array}{c}\mathrm{S} / . \\
2.842,77 \\
\end{array}$ \\
\hline \multicolumn{5}{|c|}{ Secondary tools quotation for assembly } \\
\hline 1 & $\begin{array}{l}\text { Allen key for } \\
\text { prisoner M4 }\end{array}$ & S/. 4,00 & 1 & S/. 4,00 \\
\hline 2 & Set of Taps & $\mathrm{S} / .15,00$ & 2 & S/. 30,00 \\
\hline 3 & Key 17 & S/. 20,00 & 1 & S/. 20,00 \\
\hline 4 & Key 19 & S/. 20,00 & 1 & S/. 20,00 \\
\hline 5 & $\begin{array}{c}\text { Vernier } \\
\text { measurement }\end{array}$ & S/. 35,00 & 1 & S/. 35,00 \\
\hline \multirow{2}{*}{\multicolumn{4}{|c|}{ TOTAL QUOTE OF THE ROBOT ARM }} & S/. 109,00 \\
\hline & & & & $\mathrm{S} / .2 .951,77$ \\
\hline
\end{tabular}




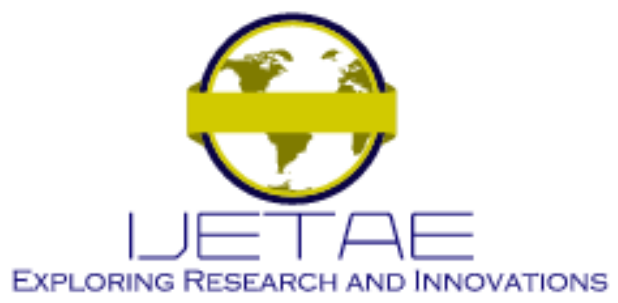

International Journal of Emerging Technology and Advanced Engineering

Website: www.ijetae.com (E-ISSN 2250-2459, Scopus Indexed, ISO 9001:2008 Certified Journal, Volume 11, Issue 10, October 2021)

\section{DisCUSSIONS}

As mentioned by the author Troncos $M$ [20], in his research work, on the design and assembly of a robot spleen with 5 degrees of freedom that allows a scan of curves in 3D, which the author for the implementation of the arm I use encoder motors and other materials as seen in Table 2 and its final budget is $\mathrm{S} / .2,951.77$, in this paper servomotors are being used because it is easier to use and its price is comfortable in the market in Table 1 The materials necessary to make a robotic arm are shown with all the basic and efficient movements in its movements. The final budget is $\mathrm{S} / .524 .00$.

As mentioned by the authors Bora P and Nandi V [21], in their research work, on the design and manufacture of a robotic arm that allows moving a robotic arm, which is possible to move through a human arm using a position sensor, it also has 4 degrees of freedom but added one more degree so that it is 5 degrees of freedom because it can move the part of the robotic arm and uses a potentiometer to perform the movement of the servomotors, in a similar way to the research work mentioned, in this paper it was thought to use the 4 degrees of freedom, but when identifying the flaw that the piece does not have a rotation, so one more degree was added so that when cleaning the window it does not have any limitation.

As mentioned by the authors Calderón and Miguel [22], in their research work, on a robotic arm that has 3 degrees of freedom, it is oriented to carry out practices in the hardware laboratory, it has a wireless Bluetooth connection and they created an application with App Inventor 2 so that it can run from the mobile device, it is identified that the mentioned research work has a disadvantage due to its use of the Bluetooth module, since it has a distance of 10 meters with line of sight compared to the transceiver that is being used at the research work that is the RF which reaches a distance of 1 kilometer with line of sight, it means if it wants to do work with a wireless connection with more range it is feasible to use RF.
The following authors Freddy $M$ and Miguel E [23], mention in their research work on design, construction and control of an automated robotic arm with 4 degrees of freedom dedicated to the manipulation of objects, it has a wireless connection using WIFI module and also a circuit for manual control with selection of direction of rotation and speed, it is identified that the aforementioned research work has two disadvantages due to its use of the WIFI module since it has a distance of 10 meters with line of sight and a manual circuit in comparison from the transceiver that is being used in the research work, which is $\mathrm{RF}$, all movements are by wireless connection.

The following authors Carlos J and Hugo E [24], mention in their research work, on the design of a robotic arm with 6 degrees of freedom for the painting of blades is an automated robot and also mention that it is necessary the 6 degrees of freedom for greater efficiency when carrying out the painting work, in this paper the 5 degrees of freedom were used since it was evaluated and verified that it is more than enough to carry out the cleaning of the window.

The following authors Anggraeni D, Sanjaya WSM and Munawwaroh M [25], mention in their research work, on the implementation of the robotic arm that is capable of picking up and placing an object, the degree used is 5 degrees of freedom, communication is through voice recognition, the result that he claimed is $85 \%$, it is one of its disadvantages since it is not as efficient when communicating as the RF transceiver that is being used in the present research work.

The following authors SK Shah, R. Mishra and G. Mohapatro [26], mention in their research work, about a design of a robotic arm with 5 degrees of freedom that can help doctors to make small samples of tissue or cell, the robot has a three-dimensional movement $(\mathrm{X}, \mathrm{Y}, \mathrm{Z})$ this works with MATLAB and ARDUINO software, for greater precision they used a stepper motor in this paper a servomotor is being used since a stepper motor has several poles instead a servo motor has two poles and is easier to connect to an Arduino. 


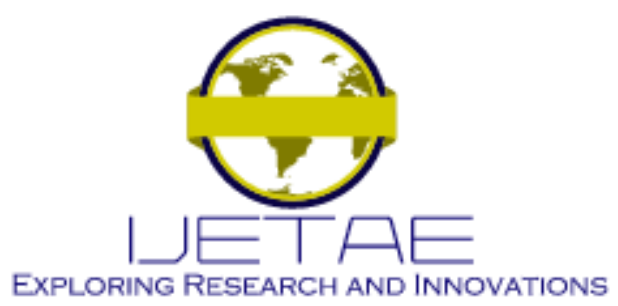

\section{International Journal of Emerging Technology and Advanced Engineering}

\section{Website: www.ijetae.com (E-ISSN 2250-2459, Scopus Indexed, ISO 9001:2008 Certified Journal, Volume 11, Issue 10, October 2021)}

\section{CONCLUSIONS}

It is concluded that it is possible to reduce accidents at heights with a robotic arm with 5 degrees of freedom, where the robot replaces the person on the scaffold and will clean three types of windows, and thus the personnel will not suffer from this type of accident.

It is concluded that if a robotic arm is large or small never mind, it will benefit the human being, because a robotic arm can perform many jobs where there is a risk of accident of the person, this technology is used by car manufacturing companies since the production it is faster and safer.

It is indicated that there is a center of specialization in work at height, where information and the correct use of the harness are provided for a good performance of a work at height, such as VAC Peru - Vertical Access Certification.

As work in the future, it is proposed to continue optimizing the robotic arm because it is a fundamental tool in work at height, therefore, it is desired to implement a robotic arm with 5 degrees of freedom, to avoid and reduce accidents at height.

\section{REFERENCES}

[1] vac vertical access certification, "VAC," vac vertical access certification, 2020 . https://www.vacperu.com.pe/contenido.php?id=1.

[2] PERÚ-UP, "Curso certificado de Persona competente para trabajos en alturas o programa de protección contra caídas | Perú Up | Cursos y Certificaciones para trabajos en altura," PERÚ-UP, 2020. https://www.peruup.com/certificacion-para-trabajos-en-altura/.

[3] conexión-esan, "Accidentes de trabajo en el Perú: ¿qué dicen las estadísticas? | Salud | Apuntes empresariales | ESAN," conexiónesan, Jan. 19, 2018. https://www.esan.edu.pe/apuntesempresariales/2018/01/accidentes-de-trabajo-en-el-peru-que-dicenlas-estadisticas/.

[4] NUEVATRIBUNA.ES, “186 muertes en los últimos 19 meses en el sector de la construcción,” NUEVATRIBUNA.ES, Jul. 30, 2019. https://www.nuevatribuna.es/articulo/actualidad/accidenteslaboralesmuerteseneltajo-laboral-construcciontrabajo/20190730142858164966.html.

[5] Arduino, "Software," $\quad 2020$. https://www.arduino.cc/en/software.

[6] SOLIDWORKS, "SolidWorks - Qué es y para qué sirve," SOLIDWORKS, 2018. https://solid-bi.es/solidworks/.

[7] D. Milanés Hermosilla and A. Castilla Pérez, "Generación de trayectorias para el brazo robótico (ArmX)," SciELO, Santiago de Cuba-Cuba, 2016.

[8] G. Jaramillo, S. J. Villa, and T. E. Paúl, "Prototipado y construcción mediante impresión en $3 \mathrm{~d}$ de un brazo inalámbrico para procesos industriales de alto riesgo," Escuela Superior Politécnica de Chimborazo, Riobamba - Ecuador, 2016.
[9] M. A. Troncos Riofrio, "Diseño y ensamble de un brazo robot como módulo de laboratorio para el escaneo de curvas en 3d," Universidad de Piura, Piura-Perú, 2016.

[10] N. L. Córdova Pérez and V. E. Romero Lindao, "IMPLEMENTACIÓN DEL BRAZO ROBÓTICO PARA LA AUSCULTACIÓN DE LA CAVIDAD BUCAL," UNIVERSIDAD DE GUAYAQUIL, GUAYAQUIL - ECUADOR, 2020.

[11] M. Á. CALDERÓN MORALES, "DISEÑO E IMPLEMENTACIÓN DE UN BRAZO ROBÓTICO BASADO EN LA PLATAFORMA ARDUINO, ORIENTADO PARA PRÁCTICAS EN EL LABORATORIO DE HARDWARE," UNIVERSIDAD DE GUAYAQUIL, GUAYAQUIL - ECUADOR, 2015.

[12] C. J. Fuentes Flores and H. E. Zunini Vasquez, "DISEÑO DE UN BRAZO ROBÓTICO DE 6 GRADOS DE LIBERTAD PARA EL PINTADO DE ÁLABES EN LA EMPRESA AYNI SAC - LA LIBERTAD," Universidad Señor de Sipán, PIMENTEL - PERÚ, 2019.

[13] INNNOVA, "Andamos colgantes," INNOVA, 2018. https://www.grupoinnova.pe/andamos-colgantes/.

[14] PERI, “¿Cuánto peso soporta un andamio?,” PERI, 2018. https://www.peri.com.pe/peri-blog/cuanto-peso-soporta-unandamio.html

[15] T-Bem, "Servomotores," T-Bem, Jun. 05, 2019. https://teslabem.com/blog/servomotores/.

[16] L. Ji, R. Cao, H. Zhou, and Z. Hou, "Servo system design and implementation based on position and speed control for the linear motor," in 2015 34th Chinese Control Conference (CCC), Sep. 2015 , vol. 2015-Septe, pp. 4223-4227, doi: 10.1109/ChiCC.2015.7260291.

[17] Inteligencia Artificial, "Grados de libertad," Inteligencia Artificial, 2020. https://freedoomforlife.wordpress.com/grados-de-libertad/.

[18] M. Dursun and S. Engin, "Deadbeat control of a DC servo motor at low speed," in Proceedings - 2018 4th International Conference on Control, Automation and Robotics, ICCAR 2018, Jun. 2018, pp. 282-286, doi: 10.1109/ICCAR.2018.8384685.

[19] Naylamp Mechatronics, "ESP32-CAM con cámara OV2640 - ESP32 WiFi," Naylamp Mechatronics, 2020. https://www.naylampmechatronics.com/espressif-esp/700-esp32cam-con-camara-ov2640-esp32-wifi.html.

[20] M. A. Troncos Riofrio, "Diseño y ensamble de un brazo robot como módelo de laboratorio para el escaneo de curvas en 3D," Universidad de Piura, Piura-Perú, 2016.

[21] P. Bora and V. Nandi, "Low cost shadow function based articulated robotic arm," in 2015 International Conference on Energy, Power and Environment: Towards Sustainable Growth, (ICEPE), Jul. 2016, pp. 1-4, doi: 10.1109/EPETSG.2015.7510079.

[22] M. Á. Calderón Morales, "Diseño e implementación de un brazo robótico basado en la plataforma Arduino, orientado para prácticas en el laboratorio de hardware," Universidad de Guayaquil Facultad de Ciencias Matemáticas y Físicas Carrera de Ingeniería en Sistemas Computacionales, Guayaquil-Ecuador, 2015.

[23] F. M. Alonzo, M. E. Bravo, and L. Caiza, "Diseño, construcción y control de un brazo robótico," Universidad San Francisco de Quito, Quito-Ecuador, 2014.

[24] C. J. Fuentes Flores and H. E. Zunini Vasquez, "Diseño de un brazo robótico de 6 grados de libertad para el pintado de álabes en la empresa ayni sac - la libertad," Universidad Señor de Sipán, Pimentel - Perú, 2019. 


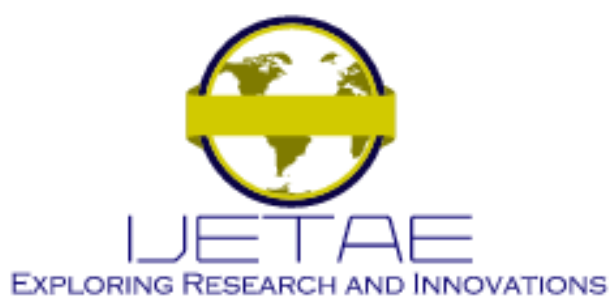

International Journal of Emerging Technology and Advanced Engineering

Website: www.ijetae.com (E-ISSN 2250-2459, Scopus Indexed, ISO 9001:2008 Certified Journal, Volume 11, Issue 10, October 2021)

[25] D. Anggraeni, W. S. M. Sanjaya, M. Munawwaroh, M. Y. S. Nurasyidiek, and I. P. Santika, "Control of robot arm based on speech recognition using Mel-Frequency Cepstrum Coefficients (MFCC) and K-Nearest Neighbors (KNN) method," in 2017 International Conference on Advanced Mechatronics, Intelligent Manufacture, and Industrial Automation (ICAMIMIA), Jun. 2018, pp. 217-222, doi: 10.1109/ICAMIMIA.2017.8387590.
[26] S. K. Shah, R. Mishra, and G. Mohapatro, "Experimental and theoretical design analysis and modeling of a CT image guided robotic arm," in ICEAST 2018 - 4th International Conference on Engineering, Applied Sciences and Technology: Exploring Innovative Solutions for Smart Society, Aug. 2018, pp. 1-4, doi: 10.1109/ICEAST.2018.8434464. 